\title{
Optimization and Analysis of Mechanical Properties for SS410 with EN19 Welded Joints using Spot Welding
}

\author{
M Mohan \\ Assistant Professor, Department of mechanical Engineering \\ Ganesh College of Engineering - 636 111, Tamil Nadu. India. \\ A Balamurugan \\ Assistant Professor, Department of mechanical Engineering \\ Ganesh College of Engineering - 636 111, Tamil Nadu. India. \\ M Ramakrishnan \\ Assistant Professor, Department of mechanical Engineering \\ Ganesh College of Engineering - 636 111, Tamil Nadu. India.
}

A Gowrishankar

Assistant Professor, Department of mechanical Engineering

Ganesh College of Engineering - 636 111, Tamil Nadu. India.

\author{
S Sivaprabu \\ Assistant Professor, Department of mechanical Engineering \\ Jayalakshmi Institute of Technology - 636 352, Tamil Nadu. India.
}

\begin{abstract}
Joining dissimilar metals has recently become very popular in industries because of the advantages associated with the weld joint. This experimental focus on an investigation of mechanical, material properties and the optimization of mechanical properties in resistance spot welding methods in lap configurations between SS410 stainless steel and carbon steel. The Taguchi method has to be used to design experiments. Welding was conducted using a spot welder. Tensile and hardness test specimens has to be prepared from the welded sheets in appropriate dimensions and tensile and hardness tests has to be performed for each specimen. The depth and width of weld nuggets were investigated. It can be concluded from the investigation that the welding joint in this method can offer moderate strength In order to improve significant mechanical and metallurgical properties of the joint, other variable parameters like voltage; electrode tip diameter etc. can also be introduced and has to be investigated.
\end{abstract}

Keywords: Optimization, Mechanical Properties, SS410, EN19, Spot Welding.

\section{INTRODUCTION SPOT WELDING}

Resistance spot welding is the resistance welding method more widely used by the industry. While in arc welding processes, electric current is used to maintain an arc between the torch and the surface of the work piece, in resistance welding methods, electric current produces heat in the piece by its flow through the work piece. The maximum amount of heat is produced where the electric resistance is maximum, which is at the surface between the sheets being joined, producing a molten nugget. Force is applied before, during and after electric current. This force is necessary in order to maintain the electric current continuity and to assure the pressure necessary to avoid defects in the joint. In spot welding the joint is produced by local fusion caused by the flow of electric current between cylindrical electrodes. The size and shape of individual spot welds are determined by the area of contact between the electrodes and the work piece. These electrodes are normally made of cooper alloys. This process deliver a big amount of energy to the spot in a very short time, thus the rest of the sheet does not have an excessive heated up. Compared with other welding process, such arc processes, resistance spot welding is easily automated, maintained and fast. Regarding the power density achieved and equipment is relatively inexpensive, the cost of each welding is one of the cheapest within all the welding processes. Resistance spot welding is widely used in assembling automobile body parts, made of thinner-gauge metals, and for manufacturing pipe, tubing and smaller structural sections. Although resistance spot welding has been used widely by the industry, this process may be difficult to control. There are 
also strong interactions between the electrical, mechanical and thermal parts of the process. Because of that there are significant difficulties in modeling the spot welding process. These difficulties produce problems to know about the quality of resistance of spot welds Thus in the practice are carrying out more spot welds than are needed for keep structural integrity.

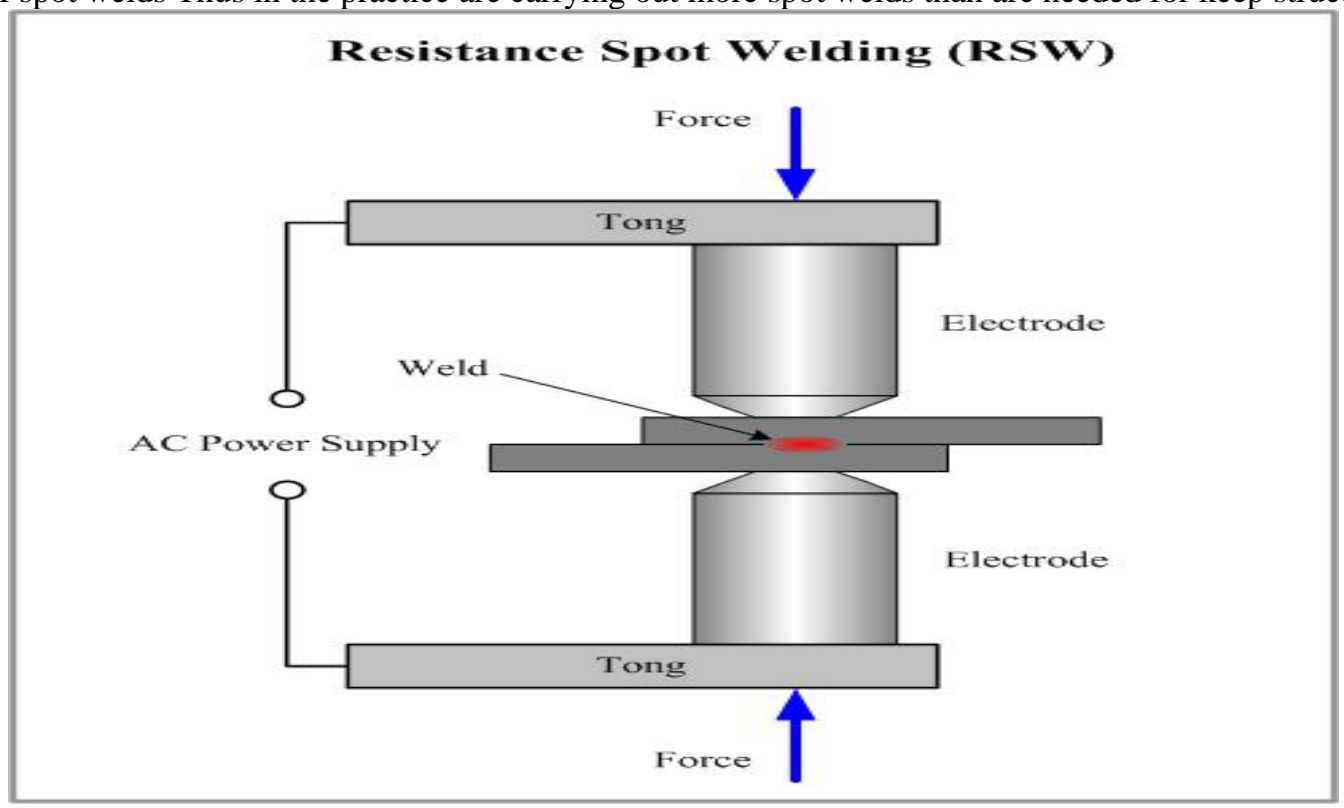

II. MATERIALS USED

\subsection{SS410}

Grade 410 is the basic martensitic stainless steel; like most non-stainless steels it can be hardened by a "quench-and-temper" heat treatment. It contains a minimum of 11.5 per cent chromium, just sufficient to give corrosion resistance properties. It achieves maximum corrosion resistance when it has been hardened and tempered and then polished. Grade 410 is a general purpose grade often supplied in the hardened, but still machinable condition, for applications where high strength and moderate heat and corrosion resistance are required. Martensitic stainless steels are optimized for high hardness, and other properties are to some degree compromised. Fabrication must be by methods that allow for poor weld ability and usually the need for a final heat treatment. Corrosion resistance of the martensitic grades is lower than that of the common austenitic grades, and their useful operating temperature range is limited by their loss of ductility at sub-zero temperatures and loss of strength by over-tempering at elevated temperatures.

\subsection{EN19}

EN 19 steel is a high tensile alloy steel and wear resistance properties and also where high strength properties are required. EN 19 is used in components subject to high stress and with a large cross section. This can include aircraft, automotive and general engineering applications for example propeller or gear shafts, connecting rods, aircraft landing gear components.

\subsection{HARDNESS VALUES ( $\mathrm{kgf} / \mathrm{mm} 2)$}

\section{EXPERIMENTAL RESULTS}

\begin{tabular}{|c|c|c|c|c|c|c|c|c|c|}
\hline SAMPLES & S1 & S2 & S3 & S4 & S5 & S6 & S7 & S8 & S9 \\
\hline SS 410 & 75 & 75 & 78 & 78 & 77 & 73 & 78 & 81 & 70 \\
\hline EN19 & 95 & 87 & 95 & 86 & 82 & 94 & 90 & 90 & 97 \\
\hline
\end{tabular}

\subsection{TENSILE STRENGTH VALUES}




\begin{tabular}{|c|c|c|c|c|}
\hline Sl. No & $\begin{array}{c}\text { Current } \\
\text { KA }\end{array}$ & $\begin{array}{c}\text { Electrode Force } \\
\text { Kg/cm }\end{array}$ & Weld Cycle & $\begin{array}{c}\text { Tensile Strength } \\
\text { N/mm }\end{array}$ \\
\hline 1 & 4 & 2 & 6 & 113.00 \\
\hline 2 & 4 & 2.5 & 8 & 129.00 \\
\hline 3 & 4 & 3 & 10 & 133.50 \\
\hline 4 & 4.5 & 2 & 8 & 122.25 \\
\hline 5 & 4.5 & 2.5 & 10 & 140.00 \\
\hline 6 & 4.5 & 3 & 5 & 150.50 \\
\hline 7 & 5 & 2 & 10 & 135.75 \\
\hline 8 & 5 & 2.5 & 6 & 124.50 \\
\hline 9 & 5 & 3 & 8 & 118.25 \\
\hline
\end{tabular}

III. PROCESS PARAMETER OPTIMIZATION FOR TENSILE STRENGTH

After finding all the observation as given in table 3.2, S/N ratio and means are calculated and also various graphs for analysis is drawn by using Minitab-16 software.

4.1 S/N Ratio Values:

\begin{tabular}{|c|c|c|c|c|c|c|}
\hline $\begin{array}{c}\text { Trial } \\
\text { no. }\end{array}$ & Designation & $\begin{array}{c}\text { Current } \\
\mathrm{KA}\end{array}$ & $\begin{array}{c}\text { Electrode } \\
\text { Force } \\
\mathrm{Kg} / \mathrm{cm}^{2}\end{array}$ & Weld Cycle & $\begin{array}{c}\text { Tensile Strength } \\
\mathrm{N} / \mathrm{mm}^{2}\end{array}$ & $\begin{array}{c}\text { S/N Ratio } \\
\text { Value }\end{array}$ \\
\hline 1 & $\mathrm{~A}_{1} \mathrm{~B}_{1} \mathrm{C}_{1}$ & 4 & 2 & 6 & 113.00 & 44.0824 \\
\hline 2 & $\mathrm{~A}_{1} \mathrm{~B}_{2} \mathrm{C}_{2}$ & 4 & 2.5 & 8 & 129.00 & 49.0664 \\
\hline 3 & $\mathrm{~A}_{1} \mathrm{~B}_{3} \mathrm{C}_{3}$ & 4 & 3 & 10 & 133.50 & 33.9794 \\
\hline 4 & $\mathrm{~A}_{2} \mathrm{~B}_{1} \mathrm{C}_{2}$ & 4.5 & 2 & 8 & 122.25 & 16.9020 \\
\hline 5 & $\mathrm{~A}_{2} \mathrm{~B}_{2} \mathrm{C}_{3}$ & 4.5 & 2.5 & 10 & 140.00 & 43.6938 \\
\hline 6 & $\mathrm{~A}_{2} \mathrm{~B}_{3} \mathrm{C}_{1}$ & 4.5 & 3 & 5 & 150.50 & 46.4029 \\
\hline 7 & $\mathrm{~A}_{3} \mathrm{~B}_{1} \mathrm{C}_{3}$ & 5 & 2 & 10 & 135.75 & 47.2722 \\
\hline 8 & $\mathrm{~A}_{3} \mathrm{~B}_{2} \mathrm{C}_{1}$ & 5 & 2.5 & 6 & 124.50 & 40.7485 \\
\hline 9 & $\mathrm{~A}_{3} \mathrm{~B}_{3} \mathrm{C}_{2}$ & 5 & 3 & 8 & 118.25 & 44.0824 \\
\hline
\end{tabular}


4.2.1 Response Table for Signal to Noise Ratios:

\begin{tabular}{|c|c|c|c|}
\hline Level & Current & Electrode Force & Weld Cycle \\
\hline 1 & 42.38 & 36.09 & 44.86 \\
\hline 2 & 35.67 & 44.50 & 35.57 \\
\hline 3 & 44.03 & 41.49 & 41.65 \\
\hline Delta & 8.37 & 8.42 & 9.28 \\
\hline Rank & 3 & 2 & 1 \\
\hline
\end{tabular}

4.2.2 Response Table for Means:

\begin{tabular}{|c|c|c|c|}
\hline Level & Current & Electrode Force & Weld Cycle \\
\hline 1 & 125.2 & 123.7 & 129.3 \\
\hline 2 & 137.6 & 131.2 & 123.2 \\
\hline 3 & 126.2 & 134.1 & 136.4 \\
\hline Delta & 12.4 & 10.4 & 13.2 \\
\hline Rank & 2 & 3 & 1 \\
\hline
\end{tabular}

4.2.3 Factors Information:

\begin{tabular}{|c|c|c|c|}
\hline FACTOR & TYPE & LEVELS & VALUES \\
\hline Current & FIXED & 3 & $4.0,4.5,5.0$ \\
\hline Electrode Force & FOXED & 3 & $2.0,2.5,3.0$ \\
\hline Weld Cycle & FIXED & 3 & $6,8,10$ \\
\hline
\end{tabular}

4.2.4 Analysis of Variance:

\begin{tabular}{|c|c|c|c|c|c|c|}
\hline Source & DF & Seq SS & Adj SS & F & P & $\begin{array}{c}\text { \% OF } \\
\text { CONTRIBUTION }\end{array}$ \\
\hline AMPS & 2 & 285.5 & 142.76 & 0.79 & 0.558 & 26 \\
\hline VOLT & 2 & 173.3 & 86.63 & 0.48 & 0.675 & 17 \\
\hline
\end{tabular}




\begin{tabular}{|c|c|c|c|c|c|c|}
\hline Gas Pressure & 2 & 263.8 & 131.88 & 0.73 & 0.577 & 24 \\
\hline Error & 2 & 360.2 & 180.11 & & & 33 \\
\hline Total & 8 & 1082.8 & & & & 100 \\
\hline
\end{tabular}
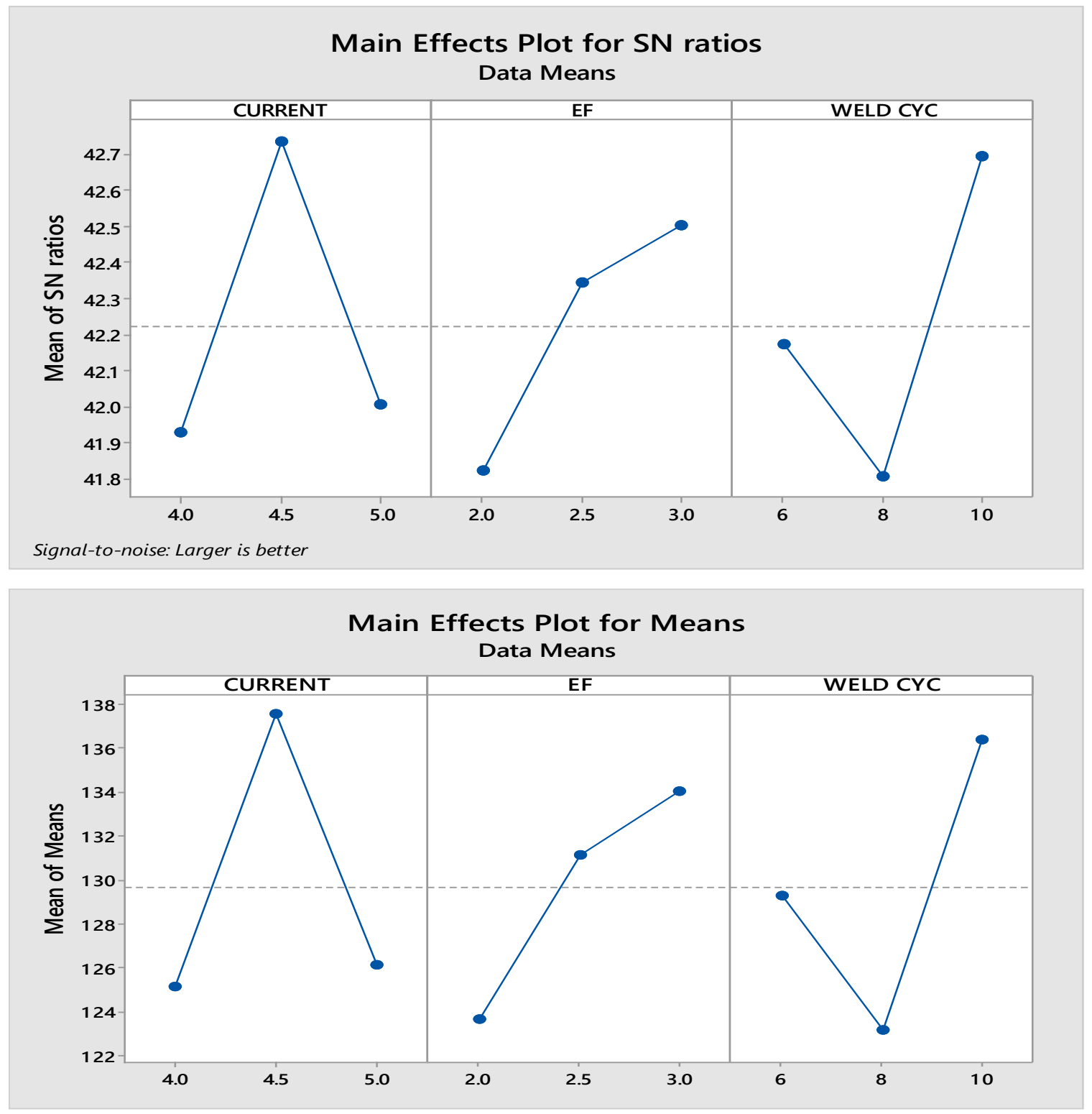

IV. CONCLUSION

The following conclusions can be inferred from the experimental study carried out:

1) The two dissimilar metals, i.e., SS 410 and EN19 Medium carbon steel can be spot welded together, producing a good weld joint with reasonably good strength.

2) In the Spot weld joint between SS 410 and EN 19 carbon steel, the weld Strength increases with Increasing welding Current.

3) In the Spot weld joint between SS 410 and MS, the weld Strength increases with Increasing Electrode force.

4) In this experimental investigation we found good mechanical strength Current $4.5 \mathrm{KA}$, Electrode force $3 \mathrm{~kg} / \mathrm{cm} 2$ and weld cycle of 5 .

5.1 Optimal Control Factor 


\section{TENSILE STRENGTH- A2 (Current -4.5) B3 (Electrode force -3 Kg/cm2) C1 (Weld cycle 6 )} 5.2 Percentage of Contribution of Process Parameter

\section{Tensile strength - Amps- $26 \%$}

\section{REFERENCES}

[1] [1] Waller D.N and Knowlson P.M (1972), "Spot weldability of high strength sheet steels”, British Welding Journal, pp.158-167.

[2] [2] Aidun D.K and Bennett R.W. (1985), "Effect of resistance welding variables on the strength of spot welded 6061-T6”, Welding Journal, 64 (12),pp.15-25.

[3] [3] Atzori B.et al. (1987), "Fatigue strength of spot welded lap joints”, Proceedings of the international welding conference, 1, pp.12-14.

[4] [4] Hirch Rogar B. (1993), “Tip Force control equal spot Weld Quality”, Welding Journal, 72, pp.57-60.

[5] [5] Darwish S.M and Al-Dekhial S.D (1998), "Statistical models for spot welding of commercial stainless steel sheets", International Journal of machine tool and manufacture, 39, pp. 1589-1610.

[6] [6] Vural M., Akkus A and Eryurek B., (2002), "Effect of weld nugget diameter on the fatigue strength of the resistance welds joints of different steel sheets”, Journal of Materials Processing Technology, 176, pp.127-132.

[7] [7] Bouyousfi B. Sahraoui T., Guessasma S. and Chaouch K.T. (2003), "Effect of process parameter on physical characteristic of spot weld joints", Materials and Design, 28, pp. 414-419.

[8] [8] Kim I.S Son J.S and Yarlagadda P.kD.V.(2003), “A study on quality improvement of GMA Welding process”, pp. 567-572.

[9] [9] Emin B., Dominique K. and Marc G (2004). “Applications of tensile testing to spot welded sheets”, Journal of material processing technology, 153154: 80-86

[10] [10] Zhang H. and Senkara J. (2006), “Resistance welding -Fundamentals and applications”, Taylors and Francis group. CRC.

[11] [11] Nizamettin K. (2007), “The influence of welding parameters on the joints of strength of resistance spot welded material and design”, Material and Design, 28, pp. 421-427.

[12] [12] Shamsul J.B and Hisyam M.M (2007), "Study of spot welding of austenitic stainless steel type 304”,. Journal of applied Science Research, 911, pp. 1494-1499.

[13] [13] Ozyurek D.(2008), “ An effect of weld current and weld atmosphere on the resistance spot Weldability of 304 austenitic stainless steel”, Material and Design, 29,pp.597-603.

[14] [14] M.Hamedi and H.Pashazadeh (2008), “Numerical study of nugget formation in resistance spot welding”, International Journal of Mechanics, issue 1 , Volume 2

[15] [15] Oscar M, Pilar, Manuel L., Manuel S.J., C.G., F.Martin,Y. Blanco (2009), “Quality prediction of resistance spot welding joints of 304 austenitic stainless steel”, Materials and Design 30, pp. 68-77

[16] [16] Tomaz, Janez G., Ivan P.(2009), “Analysis of AE during resistance spot welding”, The 10th International Conference of the Slovenian Society for Non-Destructive Testing, pp. 243-250

[17] [17] Ugur Esme (2009), “Application of Taguchi method for the optimization of resistance spot welding process”, The Arabian Journal for Science and Engineering, volume 34, number 2B, pp. 519-528

[18] [18] A. Ambroziak, M. Korzeniowski (2010), “Using resistance spot welding for joining aluminium elements in automotive industry”, archives of civil and mechanical engineering, Vol. X, pp. 5-13

[19] [19] Majid Pouranvari (2011), "Prediction of failure mode in AISI 304 resistance spot welds”, Association of Metallurgical Engineers of Serbia, UDC: 621.791.763, pp. 23-29

[20] [20] C.V. Nielsen, K.S. Friis, W. Zhang, N. Bay (2011), “Three-Sheet Spot Welding of Advanced High-Strength Steels”, Welding Journal, Vol. 90, pp. $32-40$

[21] [21] S.M.Hamidinejad, F.Kolahan,A.H. Kokabi (2012), “The modeling and process analysis of resistance spot welding on galvanized steel sheets used in car body manufacturing”,Materials and Design 34, pp. 759-767

[22] [22] Hessamoddin Moshayedi, Iradj Sattari-Far (2012), "Numerical and experimental study of nugget size growth in resistance spot welding of austenitic stainless steels”, Journal of Materials Processing Technology 212, pp.347- 354

[23] [23] Mersereau C. (1998). "How to get Top-Notch Resistance Welds with 300 series stainless Steel”, Welding Journal, 77, pp.49-51.

[24] [24] ASM Handbook (1993), "Properties and Selection: Iron, Steels and high performance alloys”, ASM International, USA, 10th Ed, Vol.1.

[25] [25] Handbook for resistance spot welding (2005). http://www.millerwelds.com/pdf/Resistance.pdf 